\title{
Kinerja Keuangan Memediasi Pengaruh Modal Intelektual dan Struktur Modal pada Nilai Perusahaan di Masa Pandemi Covid-19
}

\author{
Luh Ayu Meliani ${ }^{1}$ \\ Fakultas Ekonomi dan Bisnis \\ Universitas Udayana, Indonesia
}

\author{
Dodik Ariyanto ${ }^{2}$ \\ Fakultas Ekonomi dan Bisnis \\ Universitas Udayana, Indonesia
}

\begin{abstract}
Surel : luhayu31@gmail.com
\section{ABSTRAK}

Penelitian ini menguji pengaruh modal intelektual dan struktur modal pada nilai perusahaan dengan kinerja keuangan sebagai variabel mediasi. Sampel dipilih dengan teknik purposive sampling. Data dianalisis menggunakan analisis jalur (path analysis). Hasil analisis menunjukkan modal intelektual tidak berpengaruh pada kinerja keuangan, namun berpengaruh positif pada nilai perusahaan. Struktur modal berpengaruh positif pada kinerja keuangan, namun tidak berpengaruh pada nilai perusahaan. Kinerja keuangan berpengaruh negatif pada nilai perusahaan. Hubungan antara struktur modal dan nilai perusahaan berhasil dimediasi oleh kinerja keuangan, namun kinerja keuangan tidak berhasil menjadi mediator hubungan modal intelektual dan nilai perusahaan. Penelitian berimplikasi bagi pihak yang membutuhkan informasi mengenai nilai perusahaan pada perusahaan sub sektor farmasi dengan mempertimbangkan faktor-faktor yang mempengaruhinya apalagi dimasa pandemi Covid-19 ini.
\end{abstract}

Kata Kunci: Kinerja Keuangan; Modal Intelektual; Struktur Modal; Nilai Perusahaan.

Financial Performance Mediates the Influence of Intellectual Capital and Capital Structure on Firm Value during the Covid-19 Pandemic

\footnotetext{
ABSTRACT

This study examines the effect of intellectual capital and capital structure on firm value with financial performance as a mediating variable. The sample was selected by purposive sampling technique. Data were analyzed using path analysis. The results of the analysis show that intellectual capital has no effect on financial performance, but has a positive effect on firm value. Capital structure has a positive effect on financial performance, but has no effect on firm value. Financial performance has a negative effect on firm value. The relationship between capital structure and firm value is successfully mediated by financial performance, however, financial performance does not mediate the relationship between intellectual capital and firm value. This research has implications for those who need information about company value in pharmaceutical sub-sector companies by considering the factors that influence it, especially during the Covid 19 pandemic.
}

Keywords: Intellectual Capital; Capital Structure; Firm Value; Financial Performance.

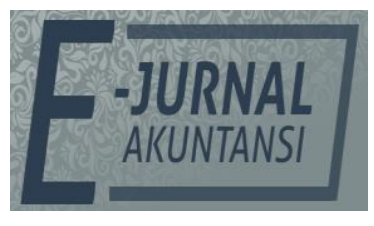

e-ISSN 2302-8556

Vol. 31 No. 10

Denpasar, Oktober 2021

Hal. 2503-2517

DOI:

10.24843/EJA.2021.v31.i10.p08

PENGUTIPAN:

Meliani, L.A., \& Ariyanto, D.

(2021). Kinerja Keuangan

Memediasi Pengaruh Modal

Intelektual dan Struktur

Modal pada Nilai Perusahaan

di Masa Pandemi Covid-19.

E-Jurnal Akuntansi, 31(10),

2503-2517

RIWAYAT ARTIKEL:

Artikel Masuk:

7 Desember 2020

Artikel Diterima:

23 Oktober 2021

Artikel dapat diakses : https://ojs.unud.ac.id/index.php/Akuntansi/index 


\section{PENDAHULUAN}

Pandemi Covid-19 telah membawa banyak perubahan yang kompleks dalam berbagai sektor kehidupan manusia. Salah satu sektor yang sangat terpukul dengan fenomena luar biasa ini adalah sektor ekonomi. Sektor ekonomi Indonesia terguncang, ditandai dengan melemahnya nilai rupiah 15-20 persen, outflows dana asing mencapai US\$10 miliar, serta menurunnya pertumbuhan ekonomi sebesar 3 persen pada kuartal I (Maret) (Rajah \& Grenville, 2020:4-8). Pemulihan ekonomi mulai diupayakan oleh pemerintah Indonesia dengan melakukan pelonggaran pembatasan sosial berskala besar (PSBB), terobosan baru ini dikenal dengan era normal baru (new normal).

Menuju era new normal menjadi momentum berjayanya industri farmasi, hal tersebut didukung dengan peningkatan trend harga saham emiten sub sektor farmasi. Secara simultan, terdapat peningkatan trend rata-rata harga saham perusahaan sub sektor farmasi periode sebelum dan saat pandemi Covid-19 yang ditunjukkan oleh Tabel 1. Pada periode Juli-September 2019 (sebelum terjadi pandemi Covid-19), rata-rata harga saham perusahaan sub sektor farmasi sebesar Rp 1.798,7. Sedangkan pada periode Juli-September 2020 (saat terjadi pandemi Covid-19), terjadi peningkatan rata-rata harga saham perusahaan sub sektor farmasi hingga mencapai Rp 1.906,9.

Tabel 1. Rata-rata Perbandingan Harga Saham Perusahaan Sub-sektor Farmasi Rata-Rata Harga Saham Sebelum-Saat Covid-19

$\begin{array}{cc}\text { Tahun } & \text { Rata-rata Harga Saham } \\ 2014-2019 & 1,054 \\ 2020 & 1,460\end{array}$

Sumber: Publikasi IDX, 2020.

Menyikapi momentum tersebut, perusahaan-perusahaan khususnya perusahaan industri farmasi harus meningkatkan inovasi dan daya saingnya ditengah era normal baru ini, yang ditandai dengan persaingan yang semakin ketat dengan memaksimalkan nilai perusahaannya. Nilai perusahaan merupakan harga saham perusahaan yang bersedia dibayar oleh investor. Nilai perusahaan yang baik dapat menciptakan sinyal positif bagi para pemangku kepentingan perusahaan yakni dapat menggambarkan prospek perusahaan masa kini serta masa depan (Mustikasari, 2018). Nilai perusahaan dapat dipengaruhi oleh berbagai faktor, diantaranya faktor internal yakni profitabilitas, modal intelektual, pembayaran dividen, ukuran perusahaan pangsa pasar relatif, leverage, likuiditas, struktur modal, dan struktur biaya, sedangkan faktor eksternal yakni suku bunga, keadaan pasar modal, dan pertumbuhan pasar (Mustikasari, 2018). Merujuk pada penelitian Ariyani \& Wirakusuma (2018), Sutriningsih, et al. (2019), Ayuba, et al. (2019) dan Ahman \& Sohn (2020) menunjukkan bahwa dari sisi internal modal intelektual dan struktur modal menjadi faktor krusial dalam mempengaruhi nilai perusahaan, sehingga dapat menjadi senjata utama peningkatan daya saing perusahaan dalam menghadapi persaingan bisnis yang ketat.

Menurut resource-based theory (RBT), perusahaan akan dapat menciptakan keunggulan kompetitif apabila perusahaan memiliki sumber daya yang unggul. Menurut Petty \& Guthrie (2000) salah satu pendekatan yang digunakan dalam penilaian dan pengukuran intangible asset adalah pendekatan intellectual capital. Firer \& Mitchell, (2003) mendefinisikan modal intelektual sebagai kekayaan 
perusahaan yang merupakan kekuatan dibalik penciptaan nilai perusahaan. Pendekatan modal intelektual di Indonesia mulai berkembang setelah diterbitkannya PSAK No.19 (revisi 2009) mengenai aktiva tidak berwujud, walaupun tidak dinyatakan secara eksplisit sebagai modal intelektual, namun setidaknya modal intelektual telah memperoleh perhatian.

Faktor yang sangat penting bagi pertumbuhan dan daya tahan perusahaan adalah struktur modal. Struktur modal perusahaan merupakan komposisi atau struktur dari liabilitas perusahaan (Kristianti, 2018). Struktur modal merupakan kunci perbaikan produktivitas dan kinerja perusahaan (Nadillah, et al. 2017) dan (Christiana, 2019). Teori struktur modal menjelaskan apakah struktur modal dapat mempengaruhi nilai dari sebuah perusahaan. Teori ini mengemukakan bahwa kebijakan pendanaan perusahaan dalam menentukan kombinasi antara utang dan ekuitas yang bertujuan untuk memaksimumkan nilai perusahaan (Kristianti, 2018).

Beberapa penelitian telah dilakukan untuk mengetahui hubungan antara modal intelektual dan struktur modal terhadap nilai perusahaan. Penelitian yang dilakukan oleh Maditinos, et al. (2010), Lin et al. (2018), Ahmed et al. (2019) dan Ahman \& Sohn (2020), menunjukkan hasil bahwa modal intelektual berpengaruh secara positif dan signifikan terhadap nilai pasar perusahaan dan kinerja keuangan. Di sisi lain, penelitian mengenai hubungan antara struktur modal dengan nilai perusahaan dilakukan oleh Vinh \& Ellis (2017) dan Ayuba, et al. (2019), menunjukkan hasil struktur modal berpengaruh negatif terhadap nilai perusahaan atau harga pasar saham. Hasil penelitian yang berbeda mengenai hubungan antara modal intelektual dan struktur modal pada nilai perusahaan ditemukan pada penelitian yang dilakukan oleh Hadiwijaya \& Rohman, (2016), Nurfauzia (2018), Uzliawati et al. (2018) dan Christiana, (2019), menunjukkan bahwa modal intelektual dan struktur modal tidak berpengaruh secara signifikan terhadap nilai perusahaan.

Perbedaan temuan atau ketidakkonsistenan hasil penelitian yang dilakukan mendorong peneliti untuk menduga bahwa terdapat pengaruh variabel lain yang tidak dikontrol oleh peneliti sebelumnya atau disebabkan oleh adanya pengaruh variabel lain yang memediasi hubungan antara modal intelektual dan struktur modal terhadap nilai perusahaan yaitu kinerja keuangan. Menurut Ariyani \& Wirakusuma (2018), perusahaan yang mampu mengelola pengetahuan dan sumber daya intelektualnya secara maksimal, maka diyakini akan mampu menciptakan value added dan competitive advantage dengan cara melakukan inovasi dan pengembangan, yang akan mendorong peningkatan kinerja perusahaan. Struktur modal merupakan kunci perbaikan produktivitas dan kinerja perusahaan (Nadillah, et al. 2017). Peningkatan kinerja perusahaan akan mendatangkan respon positif dari pasar, sehingga nilai perusahaan akan mengalami peningkatan. Penelitian terkini mengenai pengaruh modal intelektual dan struktur modal terhadap kinerja keuangan dilakukan oleh Suria (2019) yang menunjukkan bahwa modal intelektual VAIC dan struktur modal DAR memiliki pengaruh positif yang signifikan terhadap kinerja keuangan perusahaan. Selaras dengan penelitian yang dilakukan oleh Chen, et al. (2005), Firer \& Mitchell, (2003), Tan et al. (2007), dan Smriti \& Das (2017). Penelitian serupa di Indonesia dilakukan oleh Ulum (2008), 
Hadiwijaya \& Rohman (2016), Febry (2018), Ariyani \& Wirakusuma (2018), Rashid et al. (2020) dan Rizkyanti et al. (2020).

Penelitian mengidentifikasi lebih dalam penganalisaan modal intelektual dan struktur modal terhadap nilai perusahaan pada perusahaan sub sektor farmasi secara khusus dengan menginisiasi kinerja keuangan sebagai variabel mediasi. Perbedaan antara penelitian yang dilakukan dengan penelitian terdahulu yaitu adanya penambahan variabel bebas baru yaitu struktur modal yang diproksikan dengan DER, penggunaan model Tobin's $Q$ sebagai proksi atas nilai perusahaan merujuk pada penelitian Maditinos, et al. (2011), dan Ahmed, et al. (2019) data yang digunakan terfokus pada perusahaan sub sektor farmasi yang terdaftar di BEI periode 2014-2019. Sub sektor farmasi dipilih sebagai objek penelitian karena perusahaan farmasi merupakan industri yang intensif melakukan penelitian, inovatif dan seimbang dalam penggunaan sumber daya manusia serta teknologi (Ariyani \& Wirakusuma, 2018). Diperkuat dengan kondisi pandemi Covid-19 yang mengharuskan perusahaan sub sektor farmasi untuk meningkatkan kreatifitas dan inovasi dengan cepat dalam beradaptasi, serta diharapkan dapat menjadi pionir di era normal baru (new normal) melalui maksimalisasi peluang yang tersedia.

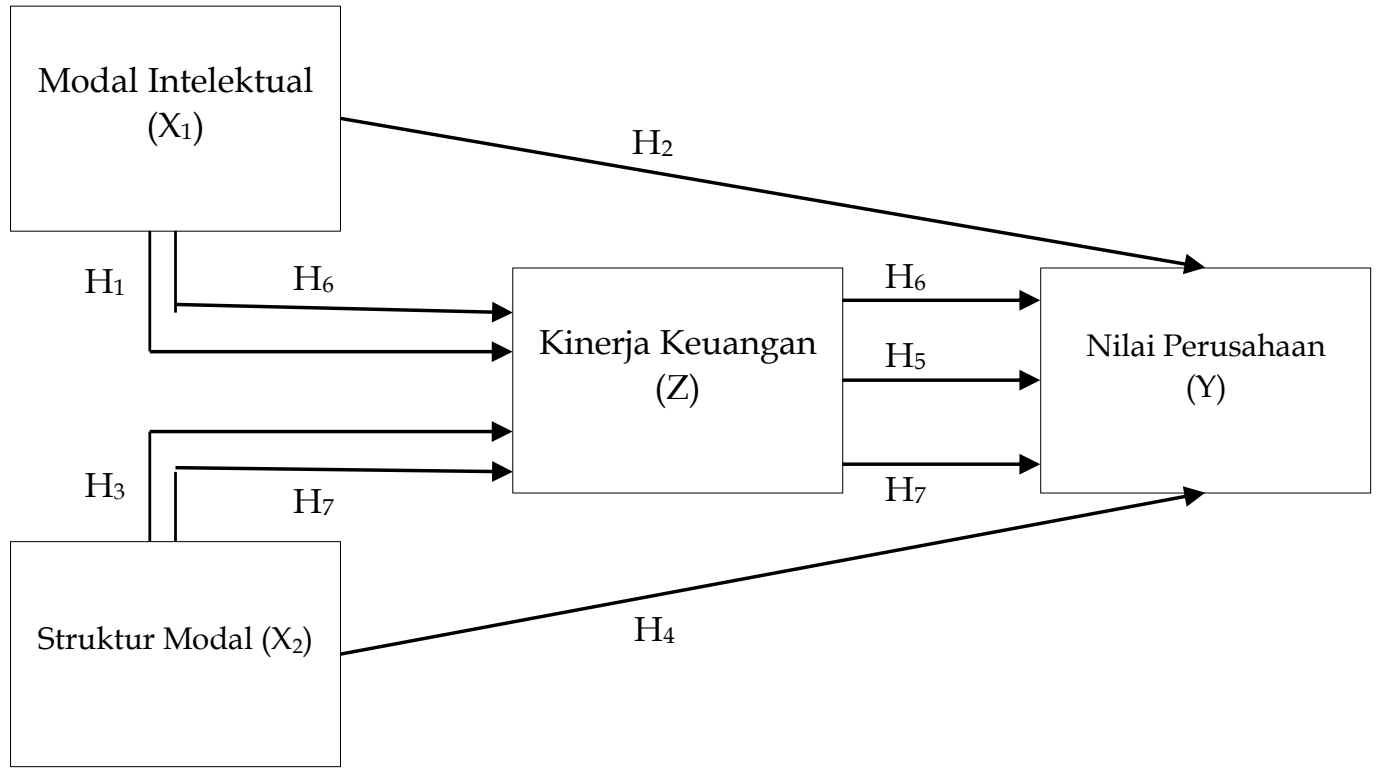

Sumber : Data Penelitian, 2020

Pendekatan sumber daya (resource-based theory) menyatakan perusahaan dapat mencapai kinerja keuangan yang baik ketika perusahaan dapat memaksimalkan pengelolaan asetnya baik yang berwujud maupun yang tidak berwujud. Kemampuan perusahaan dalam memaksimalkan pengelolaan modal intelektual mampu menciptakan value added yang akan menjadi keunggulan bersaing bagi perusahaan melalui pengembangan strategi dan inovasi yang akan mendorong peningkatan kinerja perusahaan. Hal ini selaras dengan teori stakeholder yang menyatakan pihak manajer harus melakukan berbagai aktivitas penting yang berguna bagi kepentingan para stakeholder dan harus melaporkan kembali aktivitas tersebut kepada para stakeholder sebagai bentuk 
pertanggungjawaban. Berdasarkan penelitian Firer \& Mitchell, (2003), Chen, et al. (2005), Tan, et al. (2007) dan Isanzu, (2015) membuktikan bahwa modal intelektual berpengaruh positif terhadap kinerja keuangan perusahaan. Selaras dengan penelitian yang dilakukan oleh Hadiwijaya \& Rohman (2016), Nurhasanah, et al. (2017), Ariyani \& Wirakusuma (2018), Febry (2018), Rashid, et al. (2020) dan Rizkyanti, et al. (2020). Berdasarkan pada hasil tersebut, maka dapat ditarik hipotesis penelitian yaitu sebagai berikut.

$\mathrm{H}_{1}$ : Modal intelektual berpengaruh positif pada kinerja keuangan perusahaan.

Theory of the firm menyatakan bahwa tujuan utama perusahaan adalah meningkatkan nilai perusahaan (value of the firm). Hal ini selaras dengan teori stakeholder yang menyatakan bahwa seluruh aktivitas perusahaan berujung pada penciptaan nilai bagi perusahaan itu sendiri (value creation). Ketika perusahaan memiliki kemampuan yang baik dalam penciptaan nilai perusahaan, berarti perusahaan secara tidak langsung telah mampu memenuhi kepentingan para stakeholder. Sehingga para stakeholder akan lebih menghargai perusahaan yang memiliki kualitas tersebut. Dalam konteks intellectual capital, penciptaan nilai dilakukan dengan pemanfaatan unsur-unsur intellectual capital yaitu human capital, structural capital dan customer capital dengan maksimal. Penelitian Chen, et al. (2005) dan Sirapanji \& Hatane (2015) intellectual capital dapat mempengaruhi nilai pasar perusahaan. Hal ini didukung oleh penelitian Firer \& Mitchell, (2003), Sudibya \& Restuti (2014), Juwita \& Angela (2016), Ariyani \& Wirakusuma (2018), Ahmed, et al. (2019) dan Ahman \& Sohn (2020). Berdasarkan pada hasil tersebut, maka dapat ditarik hipotesis penelitian yaitu sebagai berikut.

$\mathrm{H}_{2}$ : Modal intelektual berpengaruh positif pada nilai perusahaan.

Pendekatan sumber daya (resource-based theory) menyatakan ketika perusahaan dapat memaksimalkan pengelolaan asetnya baik yang berwujud maupun yang tidak berwujud maka perusahaan dapat mencapai kinerja keuangan yang baik. Keputusan mengenai struktur modal merupakan keputusan yang sangat penting dikarenakan hal tersebut dapat mempengaruhi daya saing perusahaan dalam jangka waktu yang panjang. Perusahaan dengan struktur modal optimal adalah perusahaan yang mempunyai hutang yang lebih kecil dibandingkan dengan modal sendiri, hal ini dikarenakan untuk menghindari adanya risiko yang lebih tinggi jika terjadi kebangkrutan (Sutriningsih, et al., 2019). Selaras dengan teori stakeholder yang menjelaskan bagaimana pengaruh stakeholder pada pengambilan keputusan dalam perusahaan yang bermuara pada peningkatan operasional perusahaan, sehingga kepentingan stakeholder akan dapat dimaksimalkan. Penelitian Hamidy, et al. (2015), Al-fisah (2016), Kristianti (2018) dan Ayuba, et al. (2019) berhasil membuktikan bahwa struktur modal dapat mempengaruhi kinerja keuangan yang digambarkan dengan profitabilitas perusahaan. Berdasarkan pada hasil tersebut, maka dapat ditarik hipotesis penelitian yaitu sebagai berikut.

$\mathrm{H}_{3}$ : Struktur modal berpengaruh positif pada kinerja keuangan.

Teori struktur modal (structural capital theory) menjelaskan bahwa struktur modal dapat mempengaruhi nilai perusahaan, dengan kombinasi keputusan pendanaan yang terdiri dari rasio antara utang dan ekuitas yang bertujuan untuk memaksimalkan nilai perusahaan. Struktur modal akan dapat meningkatkan nilai perusahaan, apabila struktur modal tersebut berada pada titik optimal- 
tercapainya keseimbangan antara tingkat risiko dan pengembalian, yang nantinya akan berpengaruh terhadap peningkatan harga saham perusahaan (Rizki, et al. 2018). Penelitian yang dilakukan oleh Hamidy, et al. (2015), Nadillah et al. (2017), Rizki et al. (2018), Uzliawati, et al. (2018), dan Sutriningsih, et al. (2019) berhasil membuktikan bahwa struktur modal yang diproksikan dengan debt to equity ratio (DER) berpengaruh positif dan signifikan terhadap nilai perusahaan. Berdasarkan pada hasil tersebut, maka dapat ditarik hipotesis penelitian yaitu sebagai berikut. $\mathrm{H}_{4}$ : Struktur modal berpengaruh positif pada nilai perusahaan.

Teori stakeholder (stakeholder theory) menyatakan bahwa investor memiliki keterlibatan dalam kinerja manajemen perusahaan untuk memaksimalkan keuntungan stakeholder. Kinerja manajemen yang baik dapat diindikasikan dengan peningkatan laba perusahaan. Sebagai salah satu stakeholder, investor akan sangat menghargai perusahaan yang memiliki laba yang stabil dan meningkat yang mengindikasikan bahwa kinerja keuangan perusahaan dalam keadaan yang memadai. Sehingga nilai tambah perusahaan akan mengalami peningkatan yang dapat mengindikasikan keunggulan daya saing perusahaan yang berkelanjutan. Penelitian Muliani, et al. (2014), Ariyani \& Wirakusuma (2018), Ayuba, et al. (2019) dan Wahyudi \& Martha (2019), menunjukkan hasil bahwa kinerja keuangan berpengaruh secara signifikan terhadap nilai perusahaan. Berdasarkan pada hasil tersebut, maka dapat ditarik hipotesis penelitian yaitu sebagai berikut.

$\mathrm{H}_{5}$ : Kinerja keuangan berpengaruh positif pada nilai perusahaan.

Dalam teori stakeholder, manajer perusahaan harus melakukan aktivitasaktivitas yang selaras dengan peningkatan manfaat yang akan diperoleh investor dari aktivitas tersebut. Tujuan utama dari teori stakeholder adalah untuk membantu manajer perusahaan dalam memahami lingkungan stakeholder dan melakukan pengelolaan secara efektif hubungan-hubungan yang ada di lingkungan perusahaan (Ulum, 2008). Berangkat dari kinerja manajemen yang baik, akan mengantarkan perusahaan dalam peningkatan nilai (value creation). Selaras dengan pendekatan sumber daya (resource-based theory) yang berasumsi bahwa perusahaan dapat bersaing secara kompetitif apabila perusahaan tersebut dapat mengelola dan memanfaatkan sumber daya berupa aset berwujud dan aset tak berwujud dengan efektif dan efisien. Pengelolaan sumber daya perusahaan yang baik, salah satunya maksimalisasi modal intelektual (intellectual capital) yang dimiliki perusahaan dapat mendorong peningkatan kinerja perusahaan dan nilai perusahaan dalam jangka panjang. oleh penelitian Sirapanji \& Hatane (2015), Hadiwijaya \& Rohman (2016), Ariyani \& Wirakusuma (2018) dan Suria (2019), berhasil menggunakan kinerja keuangan sebagai variabel yang memediasi hubungan antara modal intelektual dan nilai perusahaan. Berdasarkan pada hasil tersebut, maka dapat ditarik hipotesis penelitian yaitu sebagai berikut.

$\mathrm{H}_{6}$ : Kinerja keuangan memediasi hubungan antara modal intelelektual dan nilai perusahaan.

Tujuan yang lebih luas dari teori stakeholder adalah untuk menolong manajer korporasi dalam meningkatkan nilai dari dampak aktifitas-aktifitasnya, dan meninimalkan kerugian- kerugian bagi stakeholder. Oleh sebab itu, manajer korporasi akan bertindak sejalan dengan ekspektasi dan kepentingan stakeholder dalam operasi perusahaan, khususnya dalam keputusan pendanaan. Selaras dengan teori struktur modal yang menyatakan kombinasi optimal antara utang 
dan ekuitas yang dimiliki perusahaan akan mendorong peningkatan nilai perusahaan. Penelitian Hamidy, et al. (2015), Al-fisah (2016), Nadillah, et al. (2017); Rizki et al. (2018) dan Sutriningsih, et al. (2019), berhasil membuktikan bahwa keberadaan ROE yang memediasi hubungan antara struktur modal dengan nilai perusahaan menunjukkan hasil yang lebih tinggi daripada pengaruh langsung struktur modal pada nilai perusahaan tanpa mediasi kinerja keuangan (ROE). Berdasarkan pada hasil tersebut, maka dapat ditarik hipotesis penelitian yaitu sebagai berikut.

$\mathrm{H}_{7}$ : Kinerja keuangan memediasi hubungan antara struktur modal dan nilai perusahaan.

\section{METODE PENELITIAN}

Penelitian ini dilakukan pada perusahaan go-publik sektor industri barang konsumsi sub sektor farmasi yang terdaftar di Bursa Efek Indonesia (BEI) periode 2014-2019. Dipilihnya perusahaan publik sub sektor farmasi karena industri ini memiliki intensitas penelitian yang intensif, industri yang inovatif dan seimbang dalam penggunaan sumber daya manusia serta teknologi (Ariyani \& Wirakusuma, 2018). Kondisi pandemi Covid-19 ini, mendorong persaingan yang semakin ketat, sehingga mengharuskan perusahaan sub sektor farmasi untuk meningkatkan kreatifitas dan inovasi yang cepat dalam beradaptasi, serta memaksimalisasi kombinasi penggunaan aset berwujud maupun tak berwujud yang dimiliki perusahaan.

Jenis data pada penelitian ini adalah data kuantitatif yang bersumber dari data sekunder. Populasi yang dipilih dalam penelitian ini adalah perusahaan sektor industri barang konsumsi sub sektor farmasi yang terdaftar di Bursa Efek Indonesia (BEI). Metode penentuan sampel yang digunakan dalam penelitian ini adalah purposive sampling. Teknik purposive sampling merupakan teknik pengambilan sampel berdasarkan pada pertimbangan atau kriteria tertentu. Adapun jumlah sampel penelitian yang digunakan dalam penelitian adalah sebagai berikut:

\section{Tabel 1. Proses seleksi sampel berdasarkan kriteria}

\begin{tabular}{lr}
\hline & Jumlah \\
\hline Perusahaan go-publik yang terdaftar di BEI pada sub sektor farmasi & 10 \\
Perusahaan yang tidak menerbitkan laporan keuangan secara berturut- & \\
turut selama periode tahun 2014-2019 & $(1)$ \\
Perusahan yang mengalami delisting & $(1)$ \\
Sampel yang digunakan & 48 \\
Jumlah pengamatan selama tahun 2014-2019 & 48
\end{tabular}

Sumber : Data Penelitian, 2020

Metode ini digunakan karena peneliti memperoleh data dengan pengumpulan melalui pengamatan dari buku, jurnal, tesis, serta mengakses website resmi Bursa Efek Indonesia melalui www.idx.co.id serta website resmi masing-masing perusahaan terkait guna memperoleh informasi mengenai laporan tahunan keuangan perusahaan. Pada penelitian ini, modal intelektual diproksikan dengan model VAICTM, struktur modal diproksikan dengan Debt-to Equity Ratio (DER), kinerja keuangan diproksikan dengan Return on Equity (ROE), dan nilai perusahaan diproksikan dengan Model Tobin's Q. Pengaruh kinerja keuangan 
dalam memediasi hubungan antara modal intelektual dan struktur modal pada nilai perusahaan, diuji menggunakan metode analisis jalur (path analysis) jalur dan pengolahan data menggunakan Eviews 10. Analisis jalur merupakan perluasan dari analisis regresi linier berganda dengan menggunakan Eviews untuk menaksir hubungan kausalitas antar variabel yang telah ditetapkan sebelumnya berdasarkan teori (Ariyani \& Wirakusuma, 2018). Untuk menguji signifikansi pengaruh tidak langsung atau pengaruh variabel mediasi digunakan uji sobel. Uji sobel merupakan alat analisis untuk menguji signifikansi dari hubungan tidak langsung antar variabel independen dengan variabel dependen yang dimediasi oleh variabel mediator (Ariyani \& Wirakusuma, 2018). Model persamaan Path Analysis yang digunakan sebagai berikut.

$Z=\alpha+\beta_{1} X_{1}+\beta_{2} X_{2}+\varepsilon$

$Y=\alpha+\beta_{1} X_{1}+\beta_{2} X_{2}+\beta_{3} Z+\varepsilon$

\section{HASIL DAN PEMBAHASAN}

Hasil uji analisis jalur (path analysis) pada model-model persamaan dalam penelitian ini yaitu sebagai berikut.

Tabel 3. Analisis Jalur Persamaan Regresi

\begin{tabular}{cccccc}
\hline & Variable & Coefficient & Std. Error & t-Statistic & Prob. \\
\hline Regresi 1 & $\mathrm{C}$ & 0,066 & 0,062 & 1,064 & 0,294 \\
& $\mathrm{X}_{1}$ & $-0,014$ & 0,026 & $-0,542$ & 0,591 \\
& $\mathrm{X}_{2}$ & 0,121 & 0,012 & 9,696 & 0,000 \\
Regresi 2 & $\mathrm{C}$ & $-1,994$ & 0,649 & $-3,075$ & 0,004 \\
& $\mathrm{X}_{1}$ & 2,046 & 0,272 & 7,511 & 0,000 \\
& $\mathrm{X}_{2}$ & 0,382 & 0,238 & 1,604 & 0,117 \\
& $\mathrm{Z}$ & $-3,754$ & 1,666 & $-2,254$ & 0,030 \\
\hline
\end{tabular}

Sumber : Data Penelitian, 2020

Dari hasil analisis regresi linier berganda dapat dibentuk persamaan sebagai berikut.

$$
\begin{gathered}
Z=0,066-0,014 X 1+0,121 X 2+\varepsilon \\
Y=-1,994+2,046 X_{1}+0,382 X_{2}-3,754 Z+\varepsilon
\end{gathered}
$$

Hipotesis kesatu $\left(\mathrm{H}_{1}\right)$ dalam penelitian ini menyatakan bahwa modal intelektual berpengaruh positif pada kinerja keuangan perusahaan. Hasil analisis dengan menggunakan regresi data panel yang terdapat pada Tabel 3, modal intelektual yang diproksikan dengan VAICTM memiliki tingkat signifikansi 0,591 yang lebih besar dari $a=0,05$ atau $0,591>0,05$. Hal tersebut menunjukkan modal intelektual tidak berpengaruh pada kinerja keuangan yang berarti $\mathrm{H}_{1}$ ditolak. Pengembangan dan pengelolaan sumber daya yang dimiliki perusahaan farmasi tidak dapat berperan penting pada kontribusi kinerja keuangannya. Hasil penelitian ini tidak selaras dengan pendekatan sumber daya (resource-based theory dan teori stakeholder (stakeholder theory). Hasil penelitian ini mendukung Herawati (2010) dan Rozak \& Utami, (2020) yang menunjukkan modal intelektual tidak berpengaruh pada kinerja keuangan.

Hipotesis kedua $\left(\mathrm{H}_{2}\right)$ dalam penelitian ini menyatakan bahwa modal intelektual berpengaruh positif dan signifikan pada nilai perusahaan. Hasil analisis dengan menggunakan regresi data panel yang terdapat pada Tabel 3, modal intelektual yang diproksikan dengan VAICTM memiliki tingkat signifikansi 
0,000 yang lebih kecil dari $a=0,05$ atau $0,000<0,05$. Hal tersebut menunjukkan modal intelektual berpengaruh positif dan signifikan pada nilai perusahaan, sehingga $\mathrm{H}_{2}$ diterima. Maksimalisasi pemanfaatan modal intelektual yang dimiliki oleh perusahaan dapat menciptakan nilai tambah (value added) bagi perusahaan, yang menunjukkan seberapa berharga perusahaan dimata stakeholder. Hasil penelitian ini mendukung teori stakeholder (stakeholder theory) dan Pendekatan sumber daya (resource-based theory). Hasil penelitian yang dilakukan, mendukung penelitian oleh Firer \& Mitchell (2003), Chen, et al. (2005), Sudibya \& Restuti (2014), Sirapanji \& Hatane (2015), Juwita \& Angela (2016), Ariyani \& Wirakusuma (2018), dan Ahman \& Sohn (2020) yang menyatakan modal intelektual dapat mempengaruhi nilai perusahaan.

Hipotesis ketiga $\left(\mathrm{H}_{3}\right)$ dalam penelitian ini menyatakan bahwa struktur modal berpengaruh positif dan signifikan pada kinerja keuangan. Hasil analisis dengan menggunakan regresi data panel yang terdapat pada Tabel 3, struktur modal yang diproksikan dengan DER memiliki tingkat signifikansi 0,000 yang lebih kecil dari $\alpha=0,05$ atau $0,000<0,05$. Hal tersebut menunjukkan struktur modal berpengaruh positif dan signifikan pada nilai perusahaan, sehingga H3 diterima. Keputusan struktur modal yang tepat dan optimal dapat meningkatkan kinerja keuangan perusahaan farmasi, semakin baik struktur modal perusahaan maka akan semakin baik pula kinerja keuangan perusahaan farmasi. Hasil penelitian ini mendukung teori stakeholder (stakeholder theory) dan Pendekatan sumber daya (resource-based theory). Hasil penelitian yang dilakukan, mendukung penelitian oleh Ayuba, et al. (2019), Kristianti (2018), Al-fisah (2016) dan Hamidy, et al. (2015) yang menyatakan struktur modal dapat mempengaruhi kinerja keuangan.

Hipotesis keempat $\left(\mathrm{H}_{4}\right)$ dalam penelitian ini menyatakan bahwa struktur modal tidak berpengaruh pada nilai perusahaan. Hasil analisis dengan menggunakan regresi data panel yang terdapat pada Tabel 3, struktur modal yang diproksikan dengan DER memiliki tingkat signifikansi 0,117 yang lebih besar dari $a=0,05$ atau $0,117<0,05$. Hal tersebut menunjukkan struktur modal tidak berpengaruh pada nilai perusahaan, sehingga $\mathrm{H}_{4}$ ditolak. Penetapan berbagai skenario struktur modal dalam operasional perusahaan ternyata tidak mempengaruhi persepsi stakeholder terhadap perusahaan, sebab tidak hanya struktur modal yang menjadi satu-satunya pertimbangan dalam pengambilan keputusan investasi. Hasil penelitian ini tidak sejalan dengan teori struktur modal dan teori stakeholder (stakeholder theory). Hasil penelitian ini mendukung penelitian yang dilakukan oleh Hadiwijaya \& Rohman (2016), Nurfauzia (2018), Uzliawati, et al. (2018) dan Christiana (2019), yang menyatakan bahwa struktur modal tidak berpengaruh secara signifikan terhadap nilai perusahaan.

Hipotesis kelima $\left(\mathrm{H}_{5}\right)$ dalam penelitian ini menyatakan bahwa kinerja keuangan berpengaruh positif terhadap nilai perusahaan. Hasil analisis dengan menggunakan regresi data panel yang terdapat pada Tabel 3, kinerja keuangan yang diproksikan dengan ROE memiliki tingkat signifikansi 0,030 yang lebih kecil dari $\alpha=0,05$ atau 0,030<0,05 dengan nilai koefisien regresi $-3,754$. Hal tersebut menunjukkan kinerja keuangan berpengaruh negatif pada nilai perusahaan, sehingga $\mathrm{H}_{5}$ diterima namun dengan arah negatif. Peningkatan kinerja keuangan perusahaan direspon negatif oleh investor, sebab adanya fluktuasi laba selama 
periode pengamatan pada perusahaan sub sektor farmasi yaitu pada tahun 20162018 INAF mengalami kerugian. Hasil penelitian ini mendukung teori stakeholder (stakeholder theory) yang menyatakan bahwa investor memiliki keterlibatan dalam kinerja manajemen perusahaan untuk memaksimalkan keuntungan stakeholder. Hasil penelitian ini mendukung penelitian oleh Martikarini (2013), Tjandrakirana \& Monika (2014), Muliani, et al. (2014), Ayuba, et al. (2019), Wahyudi \& Martha (2019) dan Ariyani \& Wirakusuma (2018) yang menyatakan kinerja keuangan berpengaruh secara signifikan terhadap nilai perusahaan. Besarnya nilai e1,2 merupakan akar dari (1-(R-squared)) pada persamaan 1 \& 3 dilihat pada tabel model summary.

$\mathrm{e} 1=\sqrt{(1-(R 2))}=\sqrt{(1-0,948527)}=0,0515$

$\mathrm{e} 2=\sqrt{(1-(R 2))}=\sqrt{(1-(0,990848))}=0,009$

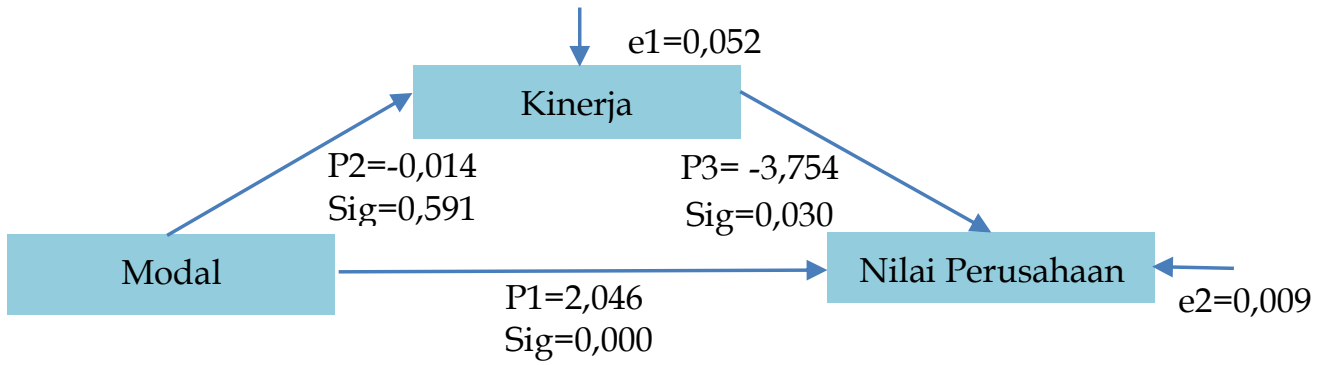

Gambar 2. Hasil Analisis Jalur

Sumber : Data Penelitian, 2020

Gambar 2, menunjukkan besarnya pengaruh modal intelektual pada kinerja keuangan adalah -0,014 dengan tingkat signifikansi sebesar 0,591, dan besarnya pengaruh langsung modal intelektual pada nilai perusahaan adalah 2,055 dengan tingkat signifikansi sebesar 0,000. Pengaruh kinerja keuangan pada nilai perusahaan yaitu $-1,498$ dengan tingkat signifikansi sebesar 0,095. Besarnya pengaruh tidak langsung atau pengaruh modal intelektual pada nilai perusahaan melalui kinerja keuangan sebagai variabel mediasi dihitung dengan mengalikan koefisien tidak langsungnya yaitu $(-0,014 \times-1,498)=0,021$. Tingkat pengaruh tidak langsung modal intelektual pada nilai perusahaan sebesar 0,021 lebih kecil dari koefisien pengaruh langsung yaitu 2,055. Berdasarkan hasil perhitungan tersebut, dapat disimpulkan bahwa antara modal intelektual dan nilai perusahaan sebenarnya terjadi pengaruh langsung, dan kinerja keuangan tidak dapat menjadi mediator dalam hubungan antara modal intelektual dan nilai perusahaan, sehingga $\mathrm{H}_{6}$ ditolak. Tata kelola modal intelektual yang baik sangat dipertimbangkan oleh stakeholder khususnya investor dalam menilai prospek ke depan perusahaan sub sektor farmasi dalam kondisi pandemi Covid-19, daripada profitabilitas perusahaan yang mengalami ketidakstabilan. Hasil penelitian ini mendukung pendekatan sumber daya (resources-based theory) dan teori stakeholder (stakeholder theory). Hasil Penelitian ini selaras dengan penelitian oleh Christiana, (2019) yang menyatakan kinerja keuangan tidak mampu memediasi pengaruh modal intelektual. Besarnya nilai e1,2 merupakan akar dari (1-(R-squared)) pada persamaan 1 \& dilihat pada tabel model summary.

$\mathrm{e} 1=\sqrt{(1-(R 2))}=\sqrt{(1-0,948527)}=0,051$

$\mathrm{e} 2=\sqrt{(1-(R 2))}=\sqrt{(1-0,978397)}=0,022$ 


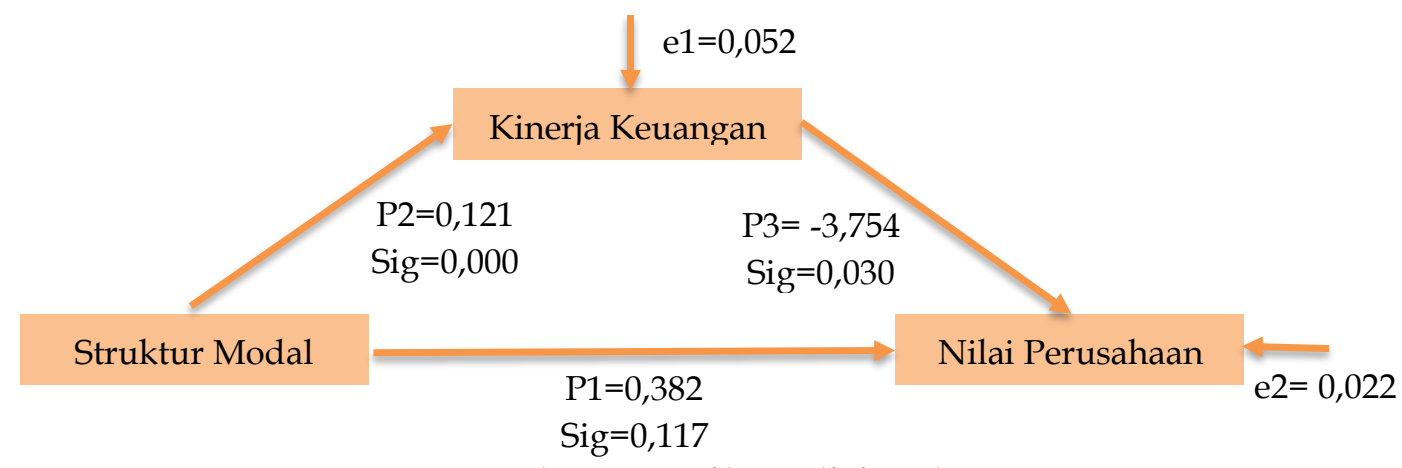

Sumber : Data Penelitian, 2020

Gambar 3. Hasil Analisis Jalur

Gambar 3, menunjukkan besarnya pengaruh struktur modal pada kinerja keuangan adalah 0,121 dengan tingkat signifikansi sebesar 0,000, dan besarnya pengaruh langsung struktur modal pada nilai perusahaan adalah 0,382 dengan tingkat signifikansi sebesar 0,117. Pengaruh kinerja keuangan pada nilai perusahaan yaitu $-3,754$ dengan tingkat signifikansi sebesar 0.030. Ditelaah melalui nilai signifikansi, struktur modal tidak berpengaruh pada nilai perusahaan $(0,117>0,05)$, struktur modal berpengaruh signifikan pada kinerja keuangan $(0,000<0,05)$, serta kinerja keuangan berpengaruh pada nilai perusahaan $(0.030<0,05)$. Berdasarkan pada tingkat signifikansi tersebut, dapat disimpulkan bahwa kinerja keuangan dapat memediasi hubungan struktur modal dengan nilai perusahaan, sehingga $\mathrm{H}_{7}$ diterima. Keputusan struktur modal yang optimal dapat meningkatkan pendapatan bersih perusahaan, menandakan baiknya kinerja keuangan perusahaan farmasi. Kinerja keuangan yang baik diapresiasi oleh stakeholder khususnya investor dengan meningkatkan investasinya pada perusahaan farmasi terkait.

Pengujian pengaruh mediasi menggunakan uji sobel tidak perlu dilakukan pada penelitian ini, dikarenakan tidak terdapat pengaruh yang sama-sama signifikan pada hubungan antar variabel. Pengaruh mediasi kinerja keuangan pada hubungan modal intelektual dan struktur modal pada nilai perusahaan dilakukan dengan menganalisis jalur (path analysis) dari hubungan antar variabel. Hasil penelitian ini selaras dengan teori struktur modal dan teori stakeholder (stakeholder theory). Hasil penelitian ini selaras dengan penelitian oleh Sutriningsih, et al. (2019), Hamidy, et al. (2015), Al-fisah (2016), Nadillah, et al. (2019) dan Rizki, et al. (2018), yang menyatakan kinerja keuangan yang digambarkan dengan profitabilitas berhasil memediasi pengaruh struktur modal terhadap nilai perusahaan.

\section{SIMPULAN}

Berdasarkan pada hasil analisis yang dilakukan sebelumnya, maka dapat disampaikan simpulan dari penelitian ini yaitu modal intelektual tidak dapat berpengaruh pada kinerja keuangan. Hal ini menunjukkan bahwa maksimalisasi modal intelektual tidak dapat berkontribusi besar pada peningkatan kinerja keuangan perusahaan farmasi, melainkan terdapat kontribusi faktor-faktor lain yang lebih kuat. Struktur modal berpengaruh positif dan signifikan pada kinerja keuangan. Hal ini menunjukkan penetapan struktur modal pada operasional 
perusahaan dengan porsi utang yang optimal, dapat meningkatkan profitabilitas perusahaan yang menandakan peningkatan kinerja keuangan perusahaan farmasi.

Modal intelektual berpengaruh positif dan signifikan pada nilai perusahaan. Hal ini menunjukkan efektifitas dan efisiensi pemanfaatan modal intelektual perusahaan dapat menciptakan nilai tambah (value added) yang mendorong peningkatan nilai perusahaan farmasi. Struktur modal tidak berpengaruh pada nilai perusahaan. Hal ini menunjukkan bahwa berbagai skenario struktur modal dalam perusahaan tidak mempengaruhi persepsi stakeholder terhadap perusahaan farmasi, sebab tidak hanya struktur modal yang menjadi satu-satunya pertimbangan dalam pengambilan keputusan investasi.

Kinerja keuangan berpengaruh negatif pada nilai perusahaan. Hal ini menunjukkan adanya volatilitas laba yang besar pada profitabilitas pertahun perusahaan farmasi, sehingga mengakibatkan investor bereaksi negatif pada kinerja keuangan perusahaan. Kinerja keuangan tidak mampu memediasi pengaruh modal intelektual pada nilai perusahaan. Hal ini menunjukkan pengaruh langsung modal intelektual pada nilai perusahaan lebih kuat dibandingkan dengan pengaruh tidak langsungnya melalui kinerja keuangan. Kinerja keuangan mampu memediasi pengaruh struktur modal pada nilai perusahaan. Hal ini menunjukkan pengaruh tidak langsung struktur modal pada nilai perusahaan melalui kinerja keuangan lebih kuat daripada pengaruh langsungnya.

Penelitian ini memiliki banyak keterbatasan yaitu terbatasnya lokasi penelitian yang digunakan yaitu hanya pada perusahaan sub sektor farmasi yang terdaftar di BEI periode 2014-2019. Sehingga diharapkan peneliti selanjutnya dapat memperluas ruang lingkup penelitian serta memperpanjang tahun pengamatan, agar hasil penelitian dapat lebih menggambarkan fenomena yang sebenarnya terjadi di masyarakat, yaitu dengan menggunakan ruang lingkup perusahaan indeks LQ-45, maupun seluruh perusahaan yang terdaftar di BEI. Peneliti selanjutnya dapat menggunakan variabel mediasi lain yang sekiranya dapat lebih mampu memediasi hubungan antara modal intelektual dan struktur modal pada nilai perusahaan, misalnya insider ownership. Peneliti selanjutnya diharapkan tidak hanya menggunakan Debt-to Equity Ratio (DER) sebagai proksi struktur modal, melainkan juga dapat menggunakan Debt-to Asset Ratio (DAR), Long Term Debt-to Equty Ratio (LDER), serta Long Term Debt-to Asset Ratio (LDAR), sehingga dapat lebih mencerminkan struktur modal perusahaan.

\section{REFERENSI}

Ahman, L. and Sohn, S. H. (2020). Impact of Intellectual Capital on Firm Performance and Market to Book Value An analysis of the extended VAIC TM model on Swedish listed firms within the healthcare sector. Thesis. University of Gethenburg School of Business, Economics and Law.

Ahmed, A. et al. (2019). Impact of Intellectual Capital on Firm Value: The Moderating Role of Managerial Ownership, SMART Journal of Business Management Studies, 15(2), p. 28. doi: 10.20944/preprints201901.0318.v1.

Al-fisah, M. C. (2016). Profitabilitas Memediasi Pengaruh Struktur Modal Terhadap Nilai Perusahaan Properti yang Terdaftar di BEI. Jurnal Ilmu Dan Riset Manajemen ISSN : 2461-0593, 5(Mei 2016) 
Ariyani, N. K. S. and Wirakusuma, M. G. (2018). 'Pengaruh Modal Intelektual Pada Nilai Perusahaan Dengan Kinerja Keuangan Sebagai Variabel Mediasi', Ejurnal Akuntansi Universitas Udayana, 25(1 Oktober 2018), pp. 464-496. doi: https://doi.org/10.24843/EJA.2018.v25.i01.p18.

Chen, M. C., S. J. Cheng, Y. Hwang. (2005). An Empirical Investigation of The Relationship between Intellectual Capital and Firms' Market Value and Financial Performances. Journal Intellectual Capital. Vol. 6 No. 2. pp. 159 176.

Febry, I. H. (2018). Pengaruh Modal Intelektual terhadap Nilai Perusahaan dengan Kinerja Keuangan sebagai Variabel Intervening. Jurnal Manajemen Bisnis Indonesia Edisi 3 Tahun 2018. Universitas Negeri Yogyakarta. https://doi.org/10.24843/eja.2018.v25.i01.p18

Firer, S. and Mitchell Williams, S. (2003). Intellectual capital and traditional measures of corporate performance. Journal of Intellectual Capital, 4(3), 348360. https:// doi.org/10.1108/14691930310487806

Hadiwijaya, R. C. and Rohman, A. (2016). Pengaruh Intellectual Capital Terhadap Kinerja Keuangan Dengan Competitive Advantage Sebagai Variabel Intervening. Jurnal Ilmu \& Riset Akuntansi, 5(6), 1-19.

Hamidy, R. R. et al. (2015). Pengaruh Struktur Modal terhadap Nilai Perusahaan dengan Profitabilitas sebagai Variabel Intervening pada Perusahaan Properti dan Real Estate di Bursa Efek Indonesia. E-Jurnal Ekonomi Dan Bisnis Universitas Udayana, 10(4.10), 665-682 ISSN: 2337-3067.

Hermawan S., Nurul M., A., (2014). Pengaruh Kinerja Keuangan terhadap Nilai Perusahaan dengan Pengungkapan Corporate Social Responsibility sebagai Variabel Pemoderasi. Jurnal Dinamika Akuntansi. Vol. 6, No. 2, September 2014,pp.103-118.ISSN2085-4277. http//journal.unnes.ac.id/nju/index.php/jda.

Juwita, R. and Angela, A. (2016). Pengaruh Intellectual Capital Terhadap Nilai Perusahaan pada Perusahaan Indeks Kompas 100 di Bursa Efek Indonesia. Jurnal Akuntansi, 8(1), 1-15.

Kristianti, I. P. (2018). Analisis Pengaruh Struktur Modal terhadap Kinerja Keuangan Perusahaan. Akuntansi Dewantara.Vol. 2 No. 1 April 2018. 2(1), 5668. e-ISSN: 2549-9637. https://doi.org/10.29230/ad.v2i1.2222.

Lin, D. jyun, Yu, W. der, Wu, C. ming, \& Cheng, T. ming. (2018). Correlation between intellectual capital and business performance of construction industry-an empirical study in Taiwan. International Journal of Construction Management, $18(3)$, 232-246. https://doi.org/10.1080/15623599.2017.1315528

Maditinos, D., Šević, Ž. and Tsairidis, C. (2010). Intellectual capital and business performance: An empirical study for the Greek listed companies. European Research Studies Journal, 13(3), 145-167. https://doi.org/10.35808/ersj/291

Martikarini, N. (2013). Pengaruh Profitabilitas, Kebijakan Hutang, Dan Dividen Terhadap Nilai Perusahaan Manufaktur Yang Terdaftar Di Bursa Efek Indonesia Periode 2009-2011. Journal of Chemical Information and Modeling, 53(9), pp. 1689-1699. doi: 10.1017/CBO9781107415324.004.

Muliani, L. E., Yuniarta, G. A. and Sinarwati, K. (2014). Pengaruh Kinerja Keuangan Terhadap Nilai Perusahaan Dengan Pengungkapan Corporate 
Social Responsibility Sebagai Variabel Pemoderasi. Jurnal Dinamika Akuntansi, pp. 103-118. doi: 10.15294/jda.v6i2.3250.

Mustikasari, S. A. (2018). Pengaruh Modal Intelektual Pada Nilai Perusahaan dengan Kinerja Keuangan Sebagai Variabel Mediasi. Tesis. doi: 10.24843/eja.2018.v25.i01.p18.

Isanzu, J. (2015). Impact of Intellectual Capital on Financial Performance of Banks in Tanzania. Journal of International Business Research and Marketing, 1(1), pp. 17-24. doi: 10.18775/jibrm.1849-8558.2015.11.3002.

Nurfauzia, A. (2018). Pengaruh Intellectual Capital Pada Nilai Perusahaan Dengan Kinerja Keuangan Sebagai Variabel Intervening (Studi pada Industri Barang Konsumsi yang terdaftar di Bursa Efek Indonesia Tahun 2010-2016 ). Jurnal Akuntansi, Ekonomi dan Manajemen Bisnis.

Nurhasanah, A., Zusan, L. and Muslih, M. (2017). Pengaruh Intellectual Capital terhadap Kinerja Keuangan Perusahaan (Studi Pada Sub Sektor Perdagangan Besar yang Listing di Bursa Efek Indonesia Periode 2012 2016). Jurnal Telkom University, 4(3), pp. 2811-2820.

Petty, R. and Guthrie, J. (2000). Intellectual capital literature review Measurement, reporting and management. Emerald Journal Library. 4425 LNCS(2), pp. 581588. doi: 10.1007/978-3-540-71496-5_54.

Rajah, R., \& Grenville, S. (2020). Keeping Indonesia' s economy afloat through the COVID-19 pandemic. In Sydney: Lowy Institute Policy Brief (Issue July).

Rashid, H. A. et al. (2020). Analyzing The Impact od Intellectual Capital on Financial Performance of Food \& Personal Care and Textile Sectors: A Comparative Analysis. Pakistan Economic and Social Review, 58, No. 1(June), pp. 35-60.

Rizki, A., Lubis, A. F., \& Sadalia, I. (2018). The Influence of Capital Structure to the Firm Value with Profitability As Intervening Variables. in The 2018 International Conference of Organizational Innovation, KnE Social Sciences, pages 220-230. DOI 10.18502/kss.v3i10.3375

Rizkyanti, R., Andriana, I. and Widiyanti, M. (2020) 'Intellectual Capital on Financial Performance in Sharia Banks in Indonesia', International Research Journal of Management, IT E Social Sciences, 7(September 2020), pp. 109-116.

Sidharta, I., \& Affandi, A. (2016). The empirical study on intellectual capital approach toward financial performance on rural banking sectors in Indonesia. International Journal of Economics and Financial Issues, 6(3), 12471253.

Smriti, N., \& Das, N. (2017). Impact of Intellectual Capital on Business Performance: Evidence from Indian Pharmaceutical Sector. Polish Journal of Management Studies, 15(1), 232-243. https://doi.org/ 10.17512/pjms. 2017.15.1.22

Suria, E. S. (2019). Pengaruh modal intelektual, tata kelola, dan struktur modal terhadap nilai perusahaan dengan kinerja keuangan sebagai variabel intervening pada perusahaan properti di BEI periode 2014-2017. Thesis. Universitas Tarumanagara.

Tan, H. P., Plowman, D. and Hancock, P. (2007). Intellectual capital and financial returns of companies. Journal of Intellectual Capital. 8(1), pp. 76-95. doi: 
10.1108/14691930710715079.

Tjandrakirana, H. R. and Monika, M. (2014). Pengaruh Kinerja Keuangan Terhadap Nilai Perusahaan Pada Perusahaan Manufaktur Yang Terdaftar Di Bursa Efek Indonesia. Jurnal Manajemen dan Bisnis Sriwijaya. Vol.12 No.(Maret 2014), pp. 1-16. doi: 10.37751/parameter.v4i1.31.

Ulum (2008). Intellectual Capital Performance Sektor Perbankan di Indonesia. Jurnal Akuntansi dan Keuangan.10(2), pp. 77-84. doi:10.9744/jak.10.2.PP.7784.

Uzliawati, L., Yuliana, A., Januarsi, Y., \& Santoso, M. I. (2018). Optimisation of Capital Structure and Firm Value. European Research Studies Journal Volume XXI, Issue 2, 2018. pp.705-713.

Vinh, X., \& Ellis, C. (2017). An empirical investigation of capital structure and firm value in Vietnam. Finance Research Letters journal. 22, pp.90-94. https://doi.org/10.1016 /j.frl.2016 .10.014.

Wahyudi, R., \& Martha, L. (2019). Analisis Modal Intelektual dan Kinerja Keuangan serta Pengaruhnya terhadap Nilai Perusahaan. INA-Rxiv, August 1, 1-14. https://doi.org/https://doi.org/10.31227/osf.io/j5e9u. 